\title{
Disturbances in Serum Electrolytes in Type 2 Diabetes Mellitus
}

\author{
Shahzad Ali Jiskani*, Saba Islamaili Khawaja, Rizwan Ali Talpur \\ Department of Pathology, Indus Medical College Hospital, Tando Muhammad Khan, Pakistan.
}

\begin{abstract}
Introduction: Diabetes mellitus is a multi-factorial disease having widespread effect on various functions of body. Electrolyte imbalance is a major problem presenting in diabetic patients due to direct effect of hyperglycemia on these electrolytes.
\end{abstract}

Objective: The aim of this study is to evaluate the electrolyte imbalance in patients with diabetes mellitus type 2.

Methods: It is a prospective study, conducted at Department of Pathology, Indus Medical College. Tando Muhammad Khan between the periods of January 2018 to March 2018. A total of 290 patients were included in this study. Group A contains 140 known diabetic patients and Group B contains 150 normal healthy individuals. Blood samples of all patients were evaluated for HbA1c, serum sodium (Na), potassium (K) and chloride $(\mathrm{Cl})$.

Results: A total of 290 patients were included in the study. Male to female ratio was higher in both diabetic and control groups. Hemoglobin $\mathrm{A} 1 \mathrm{C}(\mathrm{HbAlc})$ was found to be higher in diabetic patients as compared to normal healthy individuals with statistically significant difference ( $\mathrm{p}$ $<0.001)$. Sodium $(\mathrm{Na})$ was found to be low in diabetic group as compared to normal healthy individuals with statistically significant difference $(\mathrm{p}=0.02)$. Potassium $(\mathrm{K})$ and chloride $(\mathrm{Cl})$ did not show any difference in diabetic group and normal healthy individuals.

Conclusion: Diabetes mellitus has wide diversity of effects on major functions and cellular events. Electrolyte imbalance is a major problem in diabetic patients as disturbs the distribution of cells across the cellular compartments.

Keywords: Diabetes mellitus, Electrolytes, Sodium, Potassium, Chloride, HbA1c.

\section{INTRODUCTION}

Diabetes mellitus is group of metabolic disorders defined as hyperglycemia due to insufficiency of secretion of insulin, action of insulin or combination of both. It is classified as diabetes mellitus and type 1 and 2 . Type 1 diabetes mellitus is caused by destruction of $\beta$ - cells which lead to absolute deficiency of insulin. Type 2 diabetes is caused by defect in secretion of insulin with insulin resistance [1-3]. Diabetes mellitus is a serious disease which needs continuous and appropriate medical care, education to patients about self management and support for prevention of acute and chronic complications. The diagnosis of diabetes mellitus requires meeting of criteria including hemoglobin A1c $(\mathrm{HbA} 1 \mathrm{c}) \geq$ $6.5 \%$, fasting plasma glucose $\geq 126 \mathrm{mg} / \mathrm{dL}$ (fasting is called as no caloric intake for at least 8 hours), 2-hour plasma glucose $\geq 200 \mathrm{mg} / \mathrm{dL}$ during oral glucose tolerance test (OGTT) and random plasma glucose level $\geq 200 \mathrm{mg} / \mathrm{dL}$ in patient with symptoms of hyperglycemia [4-6].

A disturbance in electrolytes is associated with diabetes mellitus, as some electrolytes plays essential function in intermediary metabolism and cellular function [7, 8]. Electrolyte plays important roles in our body such as maintain homeostasis in the body, protection of cellular function, perfusion of tissues and acid - base balance. Common electrolytes disturbed in diabetes mellitus type includes

*Address correspondence to this author at the Department of Pathology, Indus Medical College Hospital, Tando Muhammad Khan, Pakistan.

E-mail: shahzadbaloach289@gmail.com sodium, potassium, calcium, chloride etc. [9-11]. Their deficiency is associated with shift of osmotic fluid due to hyperglycemia or total - body deficits due to osmotic diuresis. Hyperkalemia is caused due to increase in plasma tonicity caused by potassium re-distribution from intracellular to extracellular space in diabetes mellitus type 2 . Glucose is osmotically active substance, so its osmolarity will increase in hyperglycemic states, leading to movement of water out of the cells. Uncontrolled diabetes mellitus can also enhance hypovolemic hyponatremia because of osmotic diuresis $[12$, 13].

The main objective of our study is to evaluate basic electrolytes (sodium, potassium and chloride) in patients with diabetes mellitus type 2 .

\section{MATERIAL AND METHODS}

It was a prospective study, conducted at Department of Pathology, Indus Medical College Hospital, Tando Muhammad Khan. It was performed between the periods of January 2018 to March 2018. This study included 140 known diabetic patients and 150 normal healthy individuals. Patients included in this study were aged between 40 years to 70 years, known case of diabetes mellitus. Patients with metabolic syndrome, thyroid dysfunction, diabetic complications and other co-morbid were excluded from the study. Control group included normal healthy individuals with normal glycemic control and no co-morbid. 
Patients were divided into two groups. Group A contains known cases of diabetic mellitus type 2. Group B contains normal healthy individuals. Blood samples from all patients were collected in two tubes. One sample from each patient was collected in tube containing EDTA for evaluation of $\mathrm{HbA1c}$ and other sample was collected in Gel tube for evaluation of electrolytes. HbA1c level was analyzed using latex enhanced immune turbidimetric assay. Serum electrolytes were analyzed using electrolyte analyzer. All data were collected and analyzed in SPSS 21.0. P - value of $<0.05$ was considered statistically significant.

\section{RESULTS}

A total of 290 patients were selected for the study and were divided into two groups. Group A contains 140 patients known cases of diabetes mellitus type 2 and Group B contains 150 normal healthy individuals. Male to female ratio was high in both groups. In diabetic group 91 were male and 49 were female (1.85:1), while in control group 113 were male and 37 were female (3.05:1) (Table 1, Fig. 1 and 2).

Hemoglobin A1C (HbA1c) was measured in all patients. In diabetic group, mean $\mathrm{HbA1c}(\%)$ was $9.98 \pm 1.03$, while in control group it was $5.41 \pm 0.32$ (Table 2, Fig. 3). There was statistically significant difference in $\mathrm{HbAl} \mathrm{c}$ in both groups ( $\mathrm{p}$ $<0.001$ ) (Table 4). Electrolytes $(\mathrm{Na}, \mathrm{K}, \mathrm{Cl})$ were also measured in all patients. Sodium $(\mathrm{Na})(\mathrm{mmol} / \mathrm{L})$ in diabetic group was $131.2 \pm 1.94$, while in control group it was $138.4 \pm$ 1.21 (Table 3, Fig. 3). There was statistically significant difference of sodium in both groups $(p=0.02)$ (Table 4). Potassium $(\mathrm{K})(\mathrm{mmol} / \mathrm{L})$ in diabetic group was $4.1 \pm 0.49$, while in control group it was $3.8 \pm 0.21$ (Table 3, Fig. 3). There was no statistically significant difference between two groups $(\mathrm{p}=0.96)($ Table 4$)$. Chloride $(\mathrm{Cl})(\mathrm{mmol} / \mathrm{L})$ in diabetic group was $109 \pm 3.87$, while in control group it was $108 \pm 1.04$ (Table 3, Fig. 3). The difference was not statistically significant $(\mathrm{p}=1.04)$ (Table 4).
Table 1. Gender Distribution in Both Groups ( $n=290)$.

\begin{tabular}{|l|c|c|}
\hline & $\begin{array}{c}\text { Diabetic Group } \\
(\mathbf{n}=\mathbf{1 4 0})\end{array}$ & $\begin{array}{c}\text { Control Group } \\
(\mathbf{n}=\mathbf{1 5 0})\end{array}$ \\
\hline Male & 91 & 113 \\
\hline Female & 49 & 37 \\
\hline
\end{tabular}

Diabetic Group (n=140)

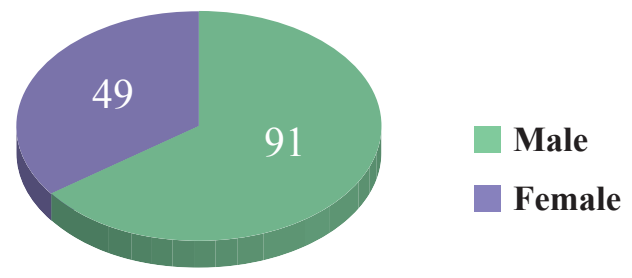

Fig. (1). Gender Distribution in Diabetic Group ( $\mathrm{n}=140)$.

\section{Control Group $(\mathbf{n}=150)$}

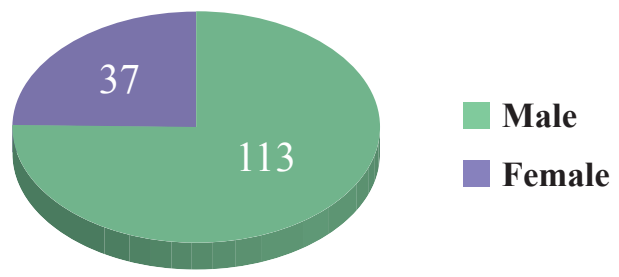

Fig. (2). Gender Distribution Control Group $(\mathrm{n}=150)$.

Table 2. HbA1c Status in Diabetic and Control Groups ( $\mathrm{n}=$ 290).

\begin{tabular}{|l|c|c|c|}
\hline & $\begin{array}{c}\text { Number of } \\
\text { cases }\end{array}$ & $\begin{array}{c}\text { HbA1c \% } \\
\text { (Mean) }\end{array}$ & $\begin{array}{c}\text { Standard Deviation } \\
\text { (SD) }\end{array}$ \\
\hline $\begin{array}{l}\text { Diabetic } \\
\text { Group }\end{array}$ & 140 & 9.98 & 1.03 \\
\hline $\begin{array}{l}\text { Control } \\
\text { Group }\end{array}$ & 150 & 5.41 & 0.32 \\
\hline
\end{tabular}

Table 3. Electrolyte (Na, K, Cl) Status in Diabetic and Control Groups $(\mathrm{n}=290)$.

\begin{tabular}{|c|c|c|c|c|}
\hline & Group & Number of cases & Mean & $\begin{array}{c}\text { Standard Deviation } \\
\text { (SD) }\end{array}$ \\
\hline \multirow{2}{*}{$\begin{array}{c}\text { Sodium (Na) } \\
(\mathbf{m m o l} / \mathbf{L})\end{array}$} & Diabetic Group & 140 & 131.2 & 1.94 \\
\cline { 2 - 5 } & Control Group & 150 & 138.4 & 1.21 \\
\hline \multirow{2}{*}{$\begin{array}{c}\text { Potassium (K) } \\
(\mathbf{m m o l} / \mathbf{L})\end{array}$} & Diabetic Group & 140 & 4.1 & 0.49 \\
\cline { 2 - 5 } & Control Group & 150 & 3.8 & 0.21 \\
\hline \multirow{2}{*}{$\begin{array}{c}\text { (mloride (Cl) } \\
\text { (mmol/L) }\end{array}$} & Diabetic Group & 140 & 109 & 4.87 \\
\cline { 2 - 5 } & Control Group & 150 & 108 & 4.03 \\
\hline
\end{tabular}




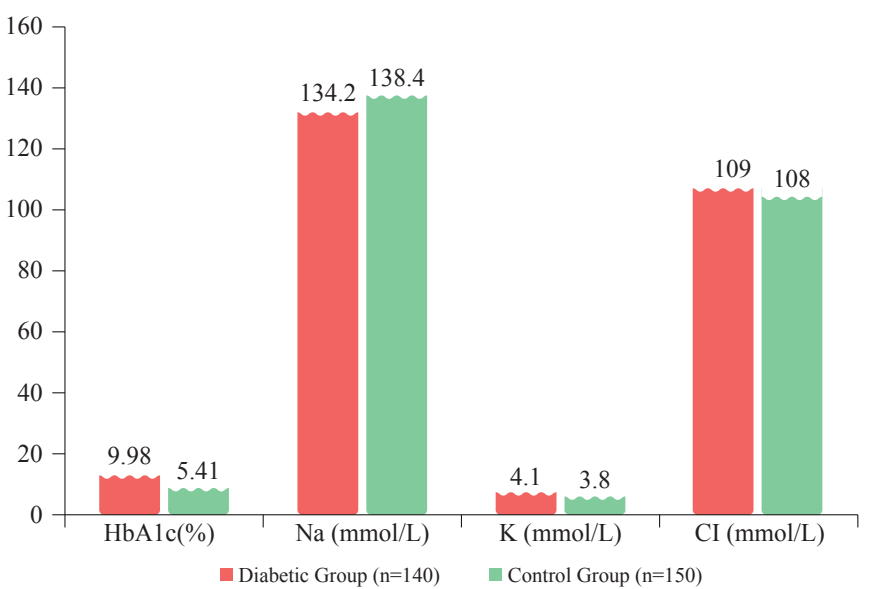

Fig. (3). HbAlc and Electrolytes $(\mathrm{Na}, \mathrm{K}, \mathrm{Cl})$ in Diabetic and Control Groups.

Table 4. Comparison of $\mathrm{HbA} 1 \mathrm{c}$ and Electrolytes $(\mathrm{Na}, \mathrm{K}, \mathrm{Cl})$ in Diabetic and Control Groups.

\begin{tabular}{|l|c|c|c|}
\hline & $\begin{array}{c}\text { Diabetic Group } \\
(\mathbf{n}=\mathbf{1 4 0 )}\end{array}$ & $\begin{array}{c}\text { Control Group } \\
(\mathbf{n}=\mathbf{1 5 0})\end{array}$ & $\mathbf{P}$ - value \\
\hline $\begin{array}{l}\text { HbA1c } \\
(\mathbf{\%})\end{array}$ & 9.98 & 5.41 & $<0.001$ \\
\hline $\begin{array}{l}\text { Sodium } \\
(\mathbf{m m o l} / \mathbf{L})\end{array}$ & 131.2 & 138.4 & 0.02 \\
\hline $\begin{array}{l}\text { Potassium } \\
(\mathbf{m m o l} / \mathbf{L})\end{array}$ & 4.1 & 3.8 & 0.96 \\
\hline $\begin{array}{l}\text { Chloride } \\
(\mathbf{m m o l} / \mathbf{L})\end{array}$ & 109 & 108 & 1.04 \\
\hline
\end{tabular}

\section{DISCUSSION}

Glucose and serum electrolytes have multi-factorial relationship. Diabetes mellitus has increase in frequency of electrolyte abnormalities. Hyperglycemia has effect on many electrolytes, leading to their abnormalities [3, 12]. Hyperglycemia enhances serum osmolality, causing movement of water out of the cells and ultimately decline in serum sodium levels by dilution. Uncontrolled diabetes mellitus is also responsible for inducing hypovolemic hyponatremia due to osmotic dieresis [14-16]. Loss of both water and solutes is caused by osmotic dieresis. Resulting changes in serum osmolarity and serum sodium concentration has strong relationship between water and solutes [17]. Hypernatremia is also a possible event presenting in patients with diabetes mellitus. It is caused by hypotonic fluid loss in urine due to osmotic diuretic effect of glycosuria [17, 18]. Hypokalemia is caused by movement of potassium from extracellular to intracellular space; may occur after insulin administration, correction of hypertonicity or $\beta^{2}$ - adrenergic stimulation. Hyperkalemia may be presented due to shifting of potassium from intracellular to extracellular space caused by deficiency of insulin or hypertonicity, or renal impairment
$[11,19]$.

In our study, we found that patients with diabetes mellitus type 2 had hyponatremia with statistically significant difference between diabetic and control groups. However, there was no statistically significant difference in potassium $(\mathrm{K})$ and chloride $(\mathrm{Cl})$ levels. Ogunleye, et al. performed a study in 2016. His study showed that diabetic patients had reduced levels of sodium, potassium, chloride, calcium, magnesium, phosphorous and sulphur as compared to non-diabetic patients. Loss of these electrolytes might occur due to decrease absorption and/or increased excretion of these electrolytes in urine, leading to deficiency or marginal states of elements in diabetic patients [7, 20]. Dasgupta, et al. found in his study that hypomagnesemia was associated with poor glycemic control and increased frequency of diabetic retinopathy and diabetic foot [21]. Datchinamoorthi, et al. showed that diabetic patients were more prone to hyperkalemia and elevated levels of chloride [12].

Our study showed some different picture of electrolyte status in diabetic patients as compared to other studies, suggesting the multi-factorial and variable scenario of electrolyte disturbances in diabetic patients.

\section{CONCLUSION}

Electrolytes imbalance has increase incidence in diabetic patients due to its diverse and multi-dimensional pathophysiology. Evaluation of electrolytes is very important in diabetic patients to manage these abnormalities at proper time and to prevent hazardous complications.

\section{CONFLICT OF INTEREST}

Declared none.

\section{ACKNOWLEDGEMENTS}

Declared none.

\section{REFERENCES}

[1] American Diabetes Association. Standards of Medical care in diabetes - 2013. Diabetes Care 2013; 36(Suppl 1): 511-66.

[2] Chiasson J, Aris-jilwan N, Bélanger R, et al. Diagnosis and treatment of diabetic ketoacidosis and the hyperglycemic hyperosmolar state. CMAJ 2003; 168(7): 859-66.

[3] Ebenexer A, Nyenwe AEK. Evidence-based management of hyperglycemic emergencies in diabetes mellitus. Diabetes Res Clin Pract 2011; 94(3): 340-51.

DOI: 10.1016/j.diabres.2011.09.012

[4] Sudhakaran S, Surani SR. Guidelines for perioperative management of the diabetic patient. Surg Res Pract 2015; 2015; 284063. DOI: $10.1155 / 2015 / 284063$

[5] Westerberg DP. Diabetic ketoacidosis: Evaluation and 
treatment. Am Fam Physician 2013; 87(5): 337-46.

[6] National Diabetes Statistics Report, 2014. Estimates of Diabetes and Its Burden in the United States. US: Centers for Disease Control and Prevention 2014.

[7] Ogunleye AZ, Asaolu MF. Evaluation of macro minerals in patients with type II diabetes mellitus in southern nigeria. Int J Biochem Res Rev 2016; 9(2): 1-9.

DOI: $10.9734 / \mathrm{IJBCRR} / 2016 / 14378$

[8] Qadir M, Amir S. Frequency of beta Thalassemia trait in pregnant anemic patients attending Khyber teaching hospital, Peshawar-Pakistan. KMUJ 2017; 9(4): 185-7.

[9] Hafeez M, Aslam M, Ali A, Rashid Y, Jafri H. Regional and ethnic distribution of beta thalassemia mutations and effect of consanguinity in patients referred for prenatal diagnosis. J Coll Physicians Sur Pak 2007; 17(3): 144-7.

[10] Gn D, Cherian S, Lakshmi K. A comparative study of electrolyte imbalances in controlled and uncontrolled diabetes mellitus. Int J Clin Biochem Res 2017; 47(1): 22-4.

[11] Article R. Electrolyte and acid-base disturbances in patients with diabetes mellitus. N Engl J Med 2015; 373: 548-59.

DOI: 10.1056/NEJMra1503102

[12] Datchinamoorthi S, Rajagopalan B, Nadu T. Research article evaluation of serum electrolytes in type ii diabetes mellitus. Int J Pharm Sci Rev Res 2016; 40(45): 251-3.

[13] Palmer BF. Regulation of potassium homeostasis. Clin J Am Soc Nephrol 2015; 10(6): 1050-60.

DOI: $10.2215 /$ CJN.08580813
[14] Liamis G, Liberopoulos E, Barkas F, et al. Diabetes mellitus and electrolyte disorders. World J Clin Cases 2014; 2(10): 488-97. DOI: 10.12998/wjcc.v2.i10.488

[15] Guder BY, Ayyildiz A, Telci L. Dysnatremia on intensive care unit admission is a stronger risk factor when associated with organ dysfunction. Minerv Anestesiol 2014; 80: 1096-104.

[16] Overgaard-Steensen C, Ring T. Clinical review: Practical approach to hyponatraemia and hypernatraemia in critically ill patients. Crit Care 2012; 17(1): 1-14. DOI: 10.1186/cc11805

[17] Liamis G, Tsimihodimos V, Doumas M, Spyrou A, Bairaktari E, Elisaf M. Clinical and laboratory characteristics of hypernatraemia in an internal medicine clinic. Nephrol Dial Transplant 2008; 23(1): 136-43. DOI: 10.1093/ndt/gfm376

[18] Darmon M, Timsit JF, Francais A, et al. Association between hypernatraemia acquired in the ICU and mortality: A cohort study. Nephrol Dial Transplant 2010; 25(8): 2510-5.

DOI: $10.1093 / \mathrm{ndt} / \mathrm{gfq} 067$

[19] Palmer BF, Clegg DJ. Physiology and pathophysiology of potassium homeostasis. Adv Physiol Educ 2016; 40(4): 480-90. DOI: 10.1152/advan.00121.2016

[20] Stelfox HT, Ahmed SB, Zygun D, Khandwala F, Laupland K. Characterization of intensive care unit acquired hyponatremia and hypernatremia following cardiac surgery. Can J Anesth 2010; 57(7): 650-8. DOI: 10.1007/s12630-010-9309-1

[21] Dasgupta A, Sarma D, Saikia UK. Hypomagnesemia in type 2 diabetes mellitus. Indian J Endocr Metab 2012; 16: 1000-3. DOI: $10.4103 / 2230-8210.103020$ 